\title{
Queuine Deficiency and Restoration in Dictyostelium discoideum and Related Early Developmental Changes
}

\author{
By ELFRIEDE SCHACHNER AND HELGA KERSTEN* \\ Institut für Physiologische Chemie der Universität Erlangen-Nürnberg, Fahrstrasse 17, \\ D-8520 Erlangen, FRG
}

(Received 10 May 1983)

\begin{abstract}
The modified deazaguanosine derivative queuosine $(\mathrm{Q})$ is found in the first position of the anticodon in the Q-family of tRNAs of eubacteria and eukaryotes. The Q-base, queuine, is inserted into tRNA in exchange for guanine. Myxamoebae of Dictyostelium discoideum cannot synthesize queuine de novo, but obtain it from bacteria, their natural food supply. When grown on bacteria, $D$. discoideum is almost fully modified with respect to $Q$, whereas the corresponding tRNAs from axenic strains, due to queuine limitation in axenic media, contain submolar amounts of Q. Queuine does not affect growth rate, but accelerates development and stimulates spore germination. To establish whether changes might be caused early in the developmental cycle by an insufficient supply of queuine, vegetative amoebae of the strain AX-2 were induced by starvation to develop in suspension culture. $Q$ deficiency in tRNA was rectified by the addition of queuine to the starvation buffer at a concentration of $10^{-7} \mathrm{M}$. During the first $12 \mathrm{~h}$, when the cells acquired aggregation competence, restoration of queuine caused (i) an increase in binding of cAMP to its surface receptors, especially to the low-affinity binding site, and (ii) characteristic changes in the time course of the synthesis of distinct proteins in response to queuine as judged from the pattern of labelled proteins separated by two-dimensional gel electrophoresis.
\end{abstract}

\section{INTRODUCTION}

The modified nucleoside queuosine $(Q)$ and glycosylated derivatives of it occur at position 34 of the anticodon of tRNA ${ }^{\mathrm{Tyr}}, \mathrm{tRNA}^{\mathrm{His}}, \mathrm{tRNA}{ }^{\mathrm{Asn}}$ and tRNA ${ }^{\text {Asp }}$ of all examined eubacteria and eukaryotes except yeast. In eukaryotes queuine [7-(( (4,5-cis-dihydroxy-2-cyclopenten-1-y])amino)-methyl)-7-deazaguanine] is inserted into the corresponding tRNAs in exchange for the guanine residue 34 by the enzyme tRNA-guanine transglycosylase (EC 2.4.2.-) (Howes \& Farkas, 1978). Eubacterial tRNAs are almost completely modified with respect to $Q$ whereas the Q content of tRNAs of eukaryotes is variable (Katze, 1975; Okada et al., 1978; Singhal et al., 1981). The extent of $Q$ modification in tRNA changes during the development of Drosophila (White \& Tener, 1973; Hosbach \& Kubli, 1979) and during erythroid differentiation of leukaemia cells (Lin et al., 1980; Shindo-Okada et al., 1981). tRNAs with G in place of Q accumulate in foetal and regenerating rat liver and in a variety of animal tumours (Okada et al., 1978; Kersten, 1982). Germ-free mice, fed on a defined diet, do not synthesize queuine de novo, indicating that the modification is derived from nutrition or from the intestinal flora (Farkas, 1980; Reyniers et al., 1981).

We have shown that in Dictyostelium discoideum the extent of $\mathrm{Q}$ modification in the $\mathrm{Q}$ family of $t R N A s$ changes during development and depends on the environmental conditions (Kersten, 1982; Dingermann et al., 1981; Ott et al., 1982). Non-axenic strains of the slime mould are

Abbretiation: Q, queuosine [7-(((4,5-cis-dihydroxy-2-cyclopenten-1-yl)-amino)-methyl)-7-deazaguanosine]. 
supplied with queuine by bacteria, but axenic strains need exogenous queuine for the tRNA modification. When the axenic strain AX-2 is grown in conventional axenic medium, $60-70 \%$ of the $Q$ family of $t R N A s$ lack $Q$. Upon addition of queuine to the medium at a concentration of $10^{-7} \mathrm{M}$, the $\mathrm{Q}$ content in these tRNAs is almost totally restored. As judged by morphological changes the addition of queuine accelerates the developmental cycle (Ott et al., 1982; Schachner et al., 1982). To investigate whether early developmental changes occur in the pattern of protein synthesis, possibly in response to queuine, vegetative cells of strain AX-2 were induced to undergo developmental transition by nutrient starvation in the absence or presence of added queuine.

During the early developmental preaggregation stage in $D$. discoideum, cAMP receptors accumulate and cAMP regulates a variety of cellular responses (see Gerisch, 1982). Furthermore, a number of changes in the pattern of protein synthesis can be observed (Alton \& Lodish, $1977 a, b$ ). In this report we show that supplying axenically grown amoebae with sufficient queuine increases the degree of binding of cAMP to its surface receptors between 6 and $12 \mathrm{~h}$ after the onset of development. Furthermore the pattern of protein synthesis during the preaggregation stage shows characteristic changes in response to queuine.

\section{METHODS}

Radiochemicals. L- ${ }^{[35}$ S $]$ Methionine $\left(1440 \mathrm{Ci} \mathrm{mmol}^{-1} ; 53.3 \mathrm{TBq} \mathrm{mmol}{ }^{-1}\right)$ was obtained from Amersham Buchler, Braunschweig, FRG, and $\left[2,8-{ }^{3} \mathrm{H}\right]$ adenosine $3^{\prime}: 5^{\prime}$ cyclic monophosphate $\left(\left[{ }^{3} \mathrm{H}\right] \mathrm{cAMP}\right)\left(38 \cdot 1 \mathrm{Ci} \mathrm{mmol}^{-1}\right.$; 1.4 TBq mmol-1) from New England Nuclear.

Preparation of organisms. Dictyostelium discoideum, strain AX-2, was grown axenically according to Watts \& Ashworth (1970). Exponentially growing cells were harvested at concentrations of $3.5 \times 10^{6}$ cells $\mathrm{ml}^{-1}$ by centrifugation at $850 \mathrm{~g}$ for $5 \mathrm{~min}$ at $4{ }^{\circ} \mathrm{C}$. The cells were washed twice with $17 \mathrm{~mm}$-phosphate buffer (pH 6.7) and resuspended in the same buffer at a final concentration of $1 \times 10^{7}$ cells $\mathrm{ml}^{-1}$ for preaggregation in shaking suspension.

Handling of Q-base. Q-base was dissolved as stock solution at a concentration of $10^{-4} \mathrm{M}$ in $17 \mathrm{mM}$-phosphate buffer, sterilized by filtration (Schleicher \& Schüll, 3354 Dassel, FRG, 0.2 $\mu \mathrm{m}$ pore size) and stored at $-20^{\circ} \mathrm{C}$. The concentration of Q-base was determined by UV absorption at $260 \mathrm{~nm}$ after filtration $\left(\varepsilon_{260} 7.5 \times\right.$ $\left.10^{3} 1 \mathrm{~mol}^{-1} \mathrm{~cm}^{-1}\right)$.

cAMP binding assay. The binding of $\left[{ }^{3} \mathrm{H}\right] \mathrm{cAMP}$ to cAMP receptors was measured during preaggregation according to Green \& Newell (1975), slightly modified according to G. Gerisch (personal communication). At the indicated time intervals, starved cells were centrifuged and resuspended at a density of $4 \times 10^{7}$ cells $\mathrm{ml}^{-1}$ in cold buffer containing $10 \mathrm{~mm}$-potassium phosphate $\mathrm{pH} 7 \cdot 5,50 \mathrm{~mm}-\mathrm{KCl}, 5 \mathrm{~mm}-\mathrm{MgCl}_{2}, 1 \mathrm{~mm}-\mathrm{EGTA}$ and $3 \mathrm{~mm}$-DTT. A $1.6 \mathrm{ml}$ sample of cell suspension was diluted in $0.8 \mathrm{ml}$ buffer and incubated with $21 \mathrm{nM}-\left[{ }^{3} \mathrm{H}\right] \mathrm{cAMP}(0.8 \mu \mathrm{Ci})$ for $45 \mathrm{~s}$ at $4{ }^{\circ} \mathrm{C}$. Aliquots $(1 \mathrm{ml}$ ) were collected on Millipore filters (Type HA, diameter $24 \mathrm{~mm}$, pore size $0.45 \mu \mathrm{m}$ ) and counted. Samples were corrected for non-specific cell-associated radioactivity, which was determined by performing the binding assay in the presence of $10^{-4} \mathrm{M}$-non-radioactive cAMP.

Labelling conditions. Cells at a density of $1 \times 10^{7} \mathrm{ml}^{-1}$ were labelled during preaggregation in shaking suspension, in the absence or presence of added queuine. Samples of $5 \times 10^{6}$ cells in $500 \mu$ were labelled with $55 \mu \mathrm{Ci} \mathrm{L}-\left[{ }^{35} \mathrm{~S}\right]$ methionine for $12 \mathrm{~h}$ (four $3 \mathrm{~h}$ periods). The cells were washed once with $17 \mathrm{~mm}$-phosphate buffer, resuspended in $100 \mu \mathrm{l}$ lysis buffer $[9.5 \mathrm{M}$-urea, $2 \%(\mathrm{v} / \mathrm{v})$ Nonidet $\mathrm{P}-40,5 \%(\mathrm{v} / \mathrm{v}) \beta$-mercaptoethanol, and $2 \%$ ampholine pH 5-7 and ampholine $\mathrm{pH} 3 \cdot 5-10$ in a ratio of $3: 2]$ and stored at $-70^{\circ} \mathrm{C}$.

Gel electrophoresis. Analysis of the labelled proteins was carried out by two-dimensional gel electrophoresis as described by O'Farrell (1975). The first dimension was isoelectric focusing with an ampholine combination of $\mathrm{pH}$ range 3.5-10 and 5-7, in a ratio of $2: 3$. This ampholine combination provides a $\mathrm{pH}$ gradient that is linear between approximately pH 4.8 and 7.8 (Dowbenko \& Ennis, 1980). The electrode solutions were $0.01 \mathrm{M}$-phosphoric acid (anode) and $0.02 \mathrm{M}-\mathrm{NaOH}$ (cathode). The proteins were focused for $15 \mathrm{~h}$ at $400 \mathrm{~V}$, followed by $1 \mathrm{~h}$ at $1000 \mathrm{~V}$. The second dimension was performed in $11.5 \%(\mathrm{w} / \mathrm{v})$ polyacrylamide gels and was carried out for $5 \mathrm{~min}$ at $200 \mathrm{~V}$, constant voltage, then at constant current with $20 \mathrm{~mA}$ per gel, until the bromphenol blue dye marker had migrated off the end of the gel. After the electrophoresis step, gels were prepared for fluorography as described by Bonner \& Laskey (1974). The gels were dried on to Aquarell paper (Selecta; Schleicher \& Schüll) under vacuum and heat. Fluorograms were exposed to Kodak X-omat film for $7 \mathrm{~d}$.

\section{RESULTS}

Dictyostelium discoideum can be grown vegetatively as single cells in a defined medium and differentiation is induced by starvation. After an early developmental preaggregation stage, the 


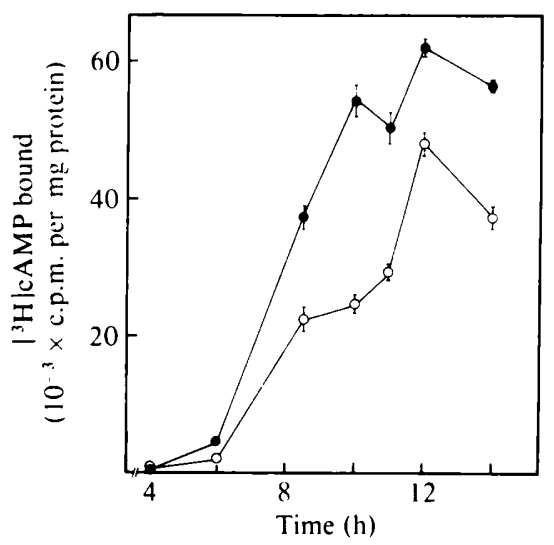

Fig. 1. Time course of the binding of $\left[{ }^{3} \mathrm{H}\right] \mathrm{cAMP}$ to its surface receptors on cells starved in buffer for 0 $14 \mathrm{~h}$ in the absence of queuine $(O)$ or in the presence of $10^{-7} \mathrm{M}$-queuine (O). $10000 \mathrm{c}$.p.m. correspond to $0.18 \mathrm{pmol}$ cAMP. The bars represent SE. The same curves were obtained in two independent, repeated experiments. The addition of queuine to the binding assay did not influence cAMP binding to the receptors.

Table 1. Binding of cAMP to surface receptors of Dictyostelium discoideum in response to queuine

The cAMP concentration was $3.3 \times 10^{-19} \mathrm{~mol}\left[{ }^{3} \mathrm{H}\right] \mathrm{cAMP}$ per cell or $6.6 \times 10^{-12} \mathrm{~mol}$ per ml assay (see Methods and legend of Fig. 1). Italicized values correspond to maxima on the binding curves (Fig. 1).

\section{Time after onset of development}

(h)

$$
8 \cdot 5
$$

$10 \cdot 0$

$11 \cdot 0$

$12 \cdot 0$

$14 \cdot 0$

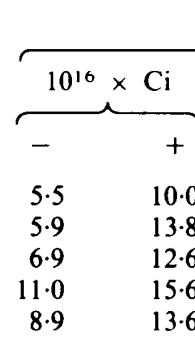

$\left[{ }^{3} \mathrm{H}\right]$ cAMP bound per cell*

* Binding to cells that had developed in the absence $(-)$ or presence $(+)$ of added queuine is shown.

cells aggregate into mounds each containing about $10^{5}$ cells. The mounds form slugs, which subsequently differentiate into mature fruiting bodies, containing spores at the top of a vacuolized stalk (see Loomis, 1975).

Early developmental changes can be observed when the cells are starved in shaking suspension (Gerisch, 1968). During this preaggregation stage, the cells become responsive to pulses of cAMP and form cAMP-binding sites on the cell surface (see Gerisch, 1982). The formation of cAMP receptors and changes in the pattern of protein synthesis during preaggregation were therefore studied to determine whether queuine influences early developmental processes.

\section{Effect of queuine on cAMP binding during development}

Vegetative cells of $D$. discoideum strain AX-2 were grown in the conventional axenic medium containing yeast extract and peptone. Under these conditions $68 \%$ of the $Q$ family of tRNAs lack queuine (Ott et al., 1982). Development was induced by starvation in phosphate buffer or in phosphate buffer supplemented with $10^{-7} \mathrm{M}$-queuine.

In the absence of queuine the binding of cAMP to surface receptors increased continuously, starting about $6 \mathrm{~h}$ after the onset of development, and reached a maximum at $12 \mathrm{~h}$ (Fig. 1, Table 1). In the presence of added queuine enhanced binding of cAMP was observed, starting at about 


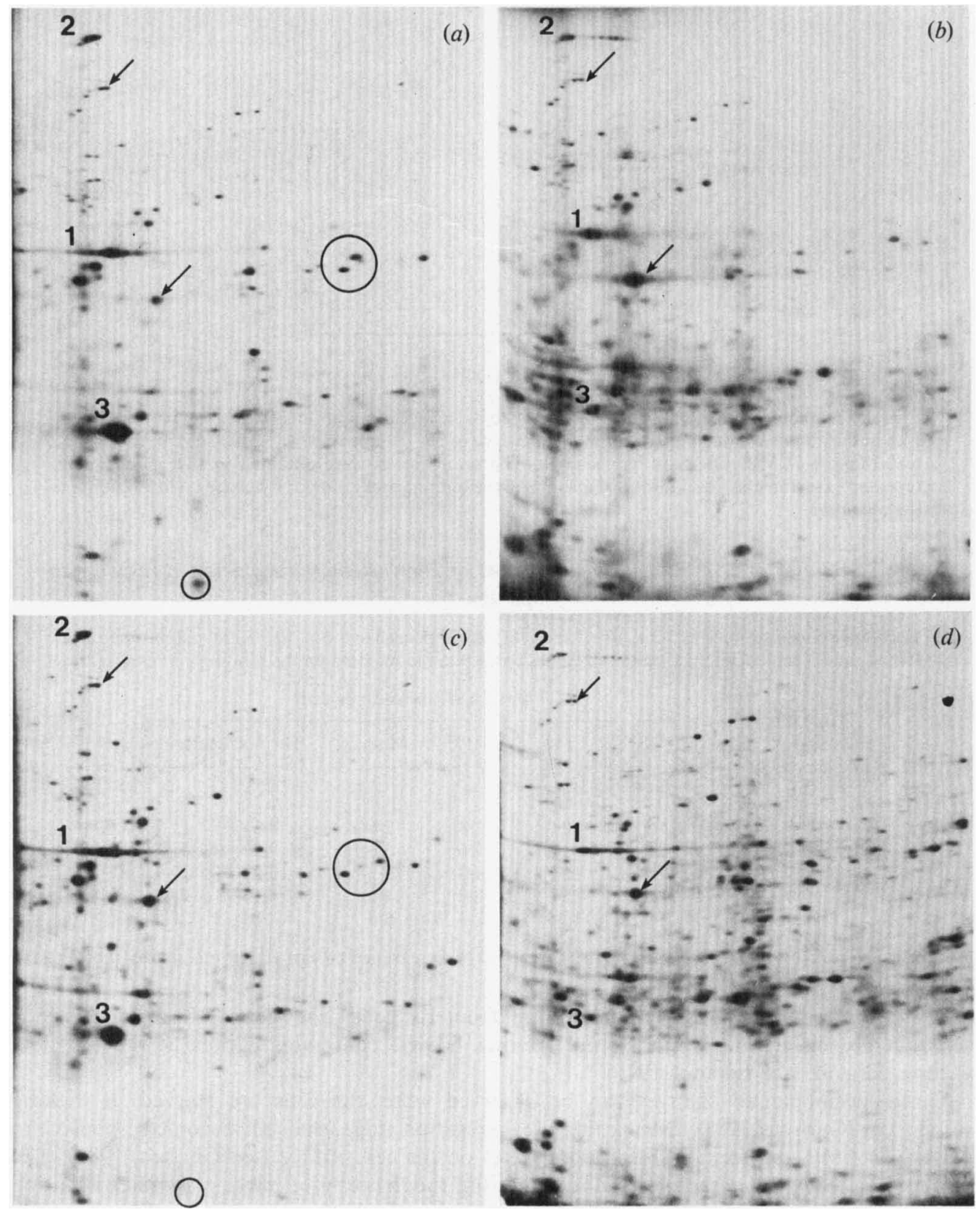

Fig. 2. Two-dimensional profiles of proteins synthesized in cells during $0-3 \mathrm{~h}(a, c)$ and 9-12 h $(b, d)$ after the onset of development in the absence $(a, b)$ and presence $(c, d)$ of added queuine. $5 \times 10^{6}$ cells in $500 \mu \mathrm{l}$ were labelled during preaggregation in suspension culture with $55 \mu \mathrm{Ci}\left[{ }^{35} \mathrm{~S}\right]$ methionine for $3 \mathrm{~h}$ (see Methods). The first dimension was isoelectric focusing from $\mathrm{pH} 4.8$ (left) to $\mathrm{pH} 7$ (right); the second dimension was performed in $11.5 \%$ polyacrylamide gels. The fluorograms were exposed to the equivalent of 200000 c.p.m. for 7 d. Prominent proteins are numbered 1, 2 and 3 . The protein referred to as number 1 corresponds to actin in its molecular weight and electrophoretic mobility. Characteristic groups of proteins that were labelled differently in cells sufficiently or insufficiently supplied with queuine are indicated by circles. The arrows point to reference proteins. The areas around spots 1,2 and 3 are shown at higher magnification in Figs 3, 4 and 5, respectively. 
$6 \mathrm{~h}$; the binding curve showed two well-separated maxima (Fig. 1) that probably represent the two cAMP-binding sites discussed by Green \& Newell (1975). From the amount of cAMP bound per cell, we calculated the number of binding sites occupied by cAMP at the concentration used in the experiment, assuming that only one molecule is bound by one specific receptor site (Table 1). Under queuine deficiency about $9 \times 10^{3}$ low-affinity sites and $18 \times 10^{3}$ high-affinity sites were occupied by cAMP per cell; with development in the presence of queuine the number of the low-affinity sites occupied by cAMP increased to $22 \times 10^{3}$ per cell and the number of the high-affinity binding sites to $25 \times 10^{3}$ per cell.

\section{Effect of queuine on the pattern of protein synthesis}

Cells in suspension culture were starved in the absence or presence of queuine and labelled with $\mathrm{L}-\left[{ }^{35} \mathrm{~S}\right]$ methionine for $12 \mathrm{~h}$ (four $3 \mathrm{~h}$ periods). The labelled proteins were analysed by the two-dimensional gel technique of O'Farrell (1975). The overall patterns of proteins synthesized during the first $3 \mathrm{~h}$ after the onset of development are shown in Fig. $2(a, c)$. These patterns were almost identical in cells that were starved in the absence and those that were starved in the presence of added queuine. A few exceptions are circled in Fig. 2. One of the predominant proteins synthesized in the early stage of differentiation is actin (Tuchman et al., 1974). Actin is always present in the 42000 molecular weight region as a characteristic elongated spot: it separates into more than one form (see Discussion). This characteristic region is identified by the number 1 in Fig. 2, and is referred to in the following sections as 'actin'. In addition to 'actin' two other proteins (spots 2 and 3) with molecular weights of about 200000 and 26000 respectively were labelled strongly during the first $3 \mathrm{~h}$ of development. When development proceeded further these three proteins showed characteristic variations in labelling in response to queuine (Fig. $2 b, d$ ), relative to other proteins. Some other changes in the pattern of protein synthesis are indicated which can probably be traced back to the stimulatory effect of queuine on the overall time course of development.

Only 'actin' and the proteins of spots 2 and 3 have been selected for further discussion, because they were heavily labelled and a decrease in their net synthesis, relative to other characteristic proteins, was clearly visible on two-dimensional gels (Figs 3-5). Quantification of particular spots after fluorography was not attempted.

Alton \& Lodish (1977a) observed that actin is synthesized predominantly during the first few hours of development. In our experiments the synthesis of 'actin' relative to reference proteins apparently started to decrease after $3 \mathrm{~h}$ in cells supplied with queuine (Fig. $3 d-f$ ) but not in queuine-deficient cells (Fig. $3 a-c$ ). A reference protein (arrowed) showed relatively enhanced labelling between 3 and $12 \mathrm{~h}$ in untreated cells and constant labelling in queuine-treated cells.

The synthesis of the protein represented in spot 2 apparently also decreased when development proceeded in response to added queuine (compare Fig. $4 a-c$ and $d-f$ ). The reference proteins (arrowed) were synthesized at an almost constant rate between 0 and $12 \mathrm{~h}$. Another prominent protein (spot 3) was also synthesized predominantly during the first $3 \mathrm{~h}$ of development. Thereafter its synthesis apparently decreased (compare Fig. $5 a, b$ and $c$ ) and here again more rapidly in cells supplied with queuine.

Each of the sections shown in Figs $3(a)-5(a), 3(b)-5(b), 3(c)-5(c), 3(d)-5(d), 3(e)-5(e)$ and $3(f)-5(f)$ respectively, are from the same gel.

\section{DISCUSSION}

The results presented here show that the addition of queuine to developing cells of Dictyostelium discoideum that were insufficiently supplied with queuine during growth causes significant changes in the synthesis of the cAMP surface receptors and of early regulated proteins.

During early development of $D$. discoideum extracellular cAMP regulates a variety of cellular responses, e.g. chemotaxis, aggregation competence, synthesis and secretion of an extracellular cAMP phosphodiesterase and its inhibitor, and signal relay (see Gerisch, 1982). These different cellular responses to the external signal are suggested to occur at the cell surface via plasma membrane cAMP receptors that start to accumulate on the cell surface about $5 \mathrm{~h}$ after the 


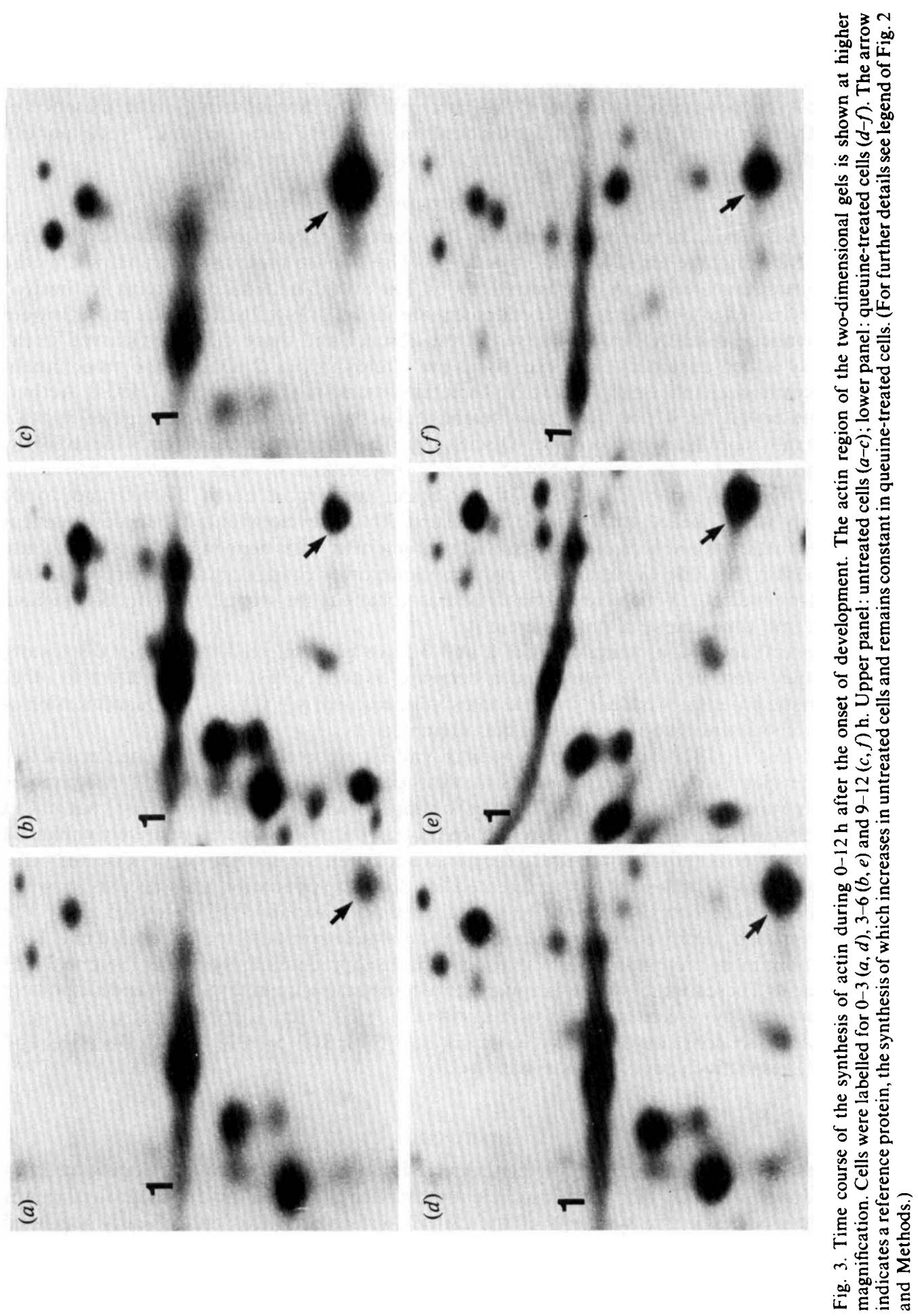




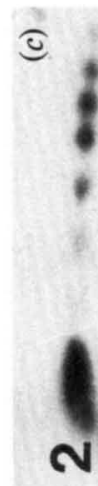

2

क

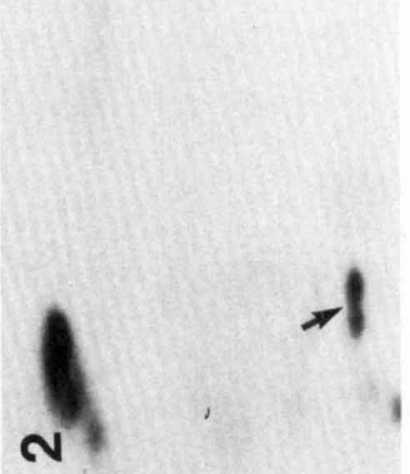

5

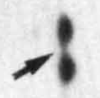

N

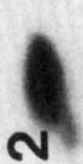

$-1$

3

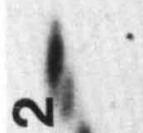

8
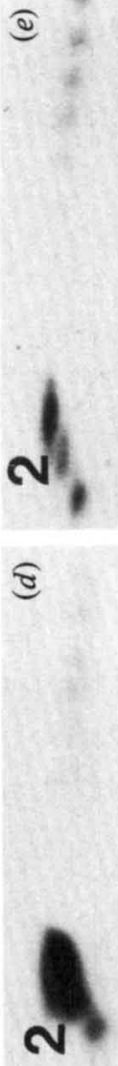

N
.

웜

ए

密

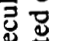

突

$8 \div$

총

点这

宕吕

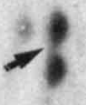

흥.

S

는

文

氙

¿ 0

造

雪

ลิธ

o 0.

है

흥

폻

응

西

든

잉

号芯

ठธ ธัّ

ขै

กิ

J 5

든.

总洁总

氜

氝

栗

的

음.

응

可

뭉

幽.

ठิ

言.

音通

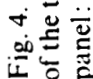



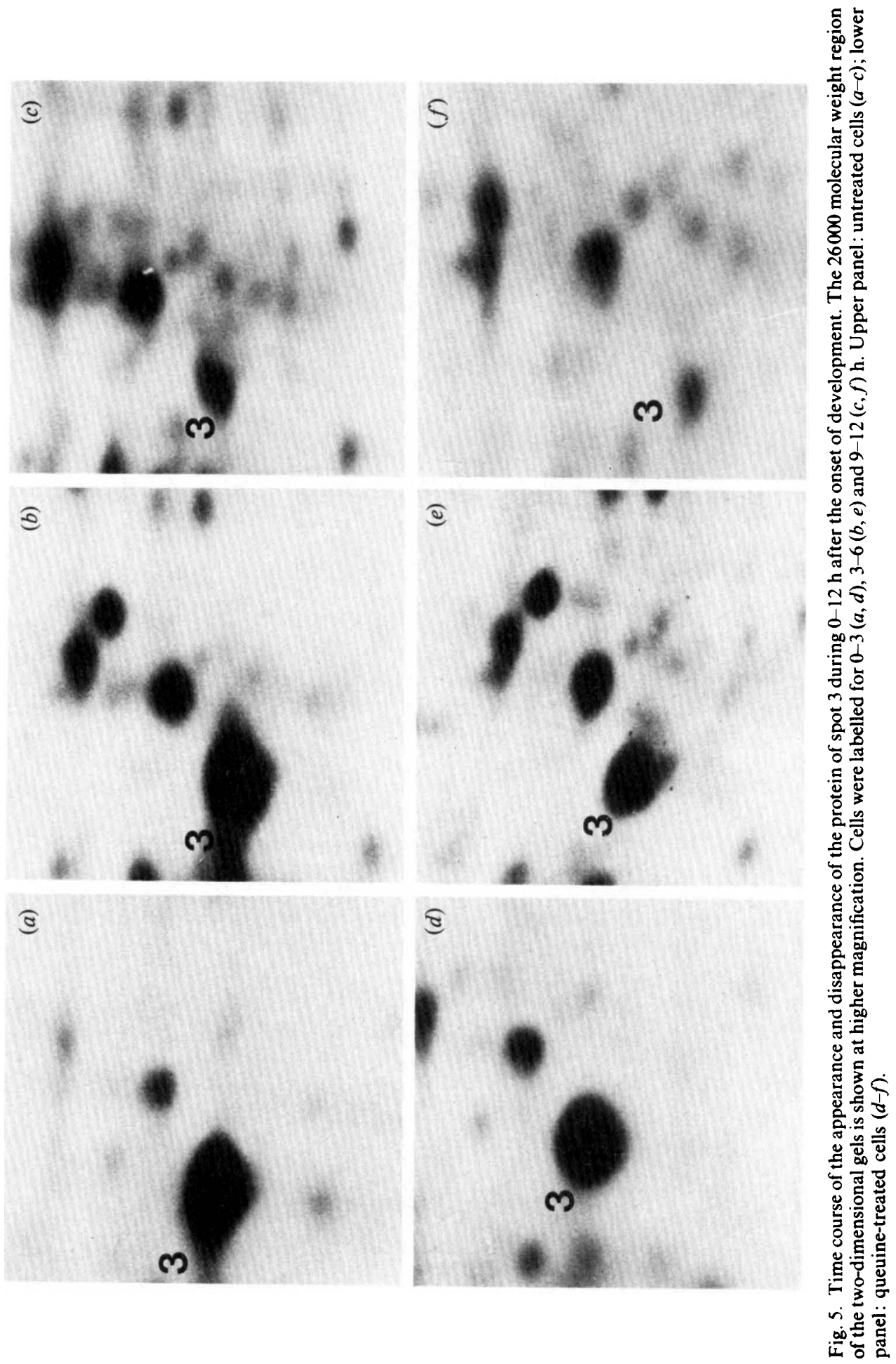
depletion of nutrients. Scatchard plots of equilibrium cAMP binding to the cell surface have been interpreted as evidence of high- and low-affinity sites (Green \& Newell, 1975), or as a result of a single class of cAMP-binding sites exhibiting positive or negative cooperativity (Coukell, 1981; Mullens \& Newell, 1978). It has been shown that the two sites accumulate consecutively and that the peak of binding activity at low cAMP concentration (high-affinity site) occurs about $2 \mathrm{~h}$ later than the peak of binding activity at high concentration (Green \& Newell, 1975). From the $\left[{ }^{3} \mathrm{H}\right]$ cAMP binding curve (Fig. 1) it is assumed that queuine in its free form or inserted into tRNA exerts its stimulatory effect on both sites. Apparently the addition of queuine favours the appearance of the low-affinity binding site. The low-affinity binding site is probably coupled to the movement response and the high-affinity binding site to the signal relay response (Green \& Newell, 1975). We assume that the stimulatory effect of queuine on the developmental cycle in $D$. discoideum is at least in part related to its effect on the cAMP receptors.

The effect of queuine on early developmental processes is also indicated by changes in the patterns of protein synthesis. The three prominent proteins observed on two-dimensional gels that have been selected for discussion are suggested to be early regulated proteins, as for example actin. Seventeen actin genes have been found in Dictyostelium, giving rise to two size classes of mRNAs (Kindle \& Firtel, 1978). Actin, labelled in vivo or synthesized in vitro from isolated RNA, can be resolved into four separate forms on the isoelectric-focusing dimension of twodimensional gels (Garrels \& Gibson, 1976; Kindle \& Firtel, 1978). Rubenstein \& Deuchler (1979) showed that two-dimensional gels resolved two major forms of actin, one of which appears to be an unacetylated form of the other. We found two major spots that changed in response to queuine (minor species might also be present) in the actin region of the twodimensional gels. The 200000 molecular weight protein (spot 2 in Fig. 2) corresponds in molecular weight and electrophoretic mobility to the myosin heavy chain described by Clarke $\&$ Spudich (1974). The synthesis of this protein apparently changes also in response to queuine. Rahmsdorf et al. (1978) found that extracts from $D$. discoideum that had been exposed to external pulses of cAMP showed an enhanced phosphorylation of the myosin heavy chain. The disappearance of spot 2 and the appearance of minor spots with the same molecular weight but multiple isoelectric points (see Fig. 4) might be related to the dephosphorylation of the myosin heavy chain. On the basis of molecular weight and electrophoretic mobility, the third protein, which responded to queuine in a similar way to actin, might be identical with one of the early regulated carbohydrate-binding proteins (Siu et al., 1976; Ma \& Firtel, 1978).

Strains of $D$. discoideum grown on bacteria are metabolically distinct from axenic strains cultivated in axenic media (Loomis, 1975). At least some of these metabolic differences may be caused by the insufficient supply of axenic strains with queuine. The restoration of queuine increases the Q content of the corresponding tRNAs (Ott et al., 1982). Experimental evidence has been presented suggesting that alterations of the $Q$ content in tRNA are involved in control mechanisms at the translational level (see Kersten, 1982).

Restoration of queuine to axenically grown cells stimulates development as indicated by morphological changes (Schachner et al., 1982). The alterations of $\left[{ }^{3} \mathrm{H}\right] \mathrm{cAMP}$ binding to its surface receptors and of the synthesis of early developmentally regulated proteins may be caused by transiently free intracellular queuine or by Q-containing tRNAs. The molecular mechanism by which $Q$ exerts its effect on cell metabolism is currently being investigated.

We thank Dr G. Gerisch for helpful advice with the cAMP binding assay and for stimulating discussions. Queuine was a kind gift of Dr Nishimura, and was synthesized by Drs H. Akimoto and H. Nomura of Central Research Laboratories, Takada Chemical Ind. Ltd, Osaka. We thank Mrs Sonja Noeth for help with the manuscript.

This work was supported by the Deutsche Forschungsgemeinschaft (grant $\mathrm{Ke} \mathrm{98/16)}$ ) and the Fond der Chemischen Industrie.

\section{REFERENCES}

ALton, T. H. \& Lodish, H. F. (1977a). Developmental changes in messenger RNAs and protein synthesis in Dictyostelium discoideum. Developmental Biology 60, 180-206.
Alton, T. H. \& Lodish, H. F. (1977b). Synthesis of developmentally regulated proteins in Dictyostelium discoideum which are dependent on continued cellcell interaction. Developmental Biology 60, 207-216. 
Bonner, W. M. \& Laskey, R. A. (1974). A film detection method for tritium-labeled proteins and nucleic acids in polyacrylamide gels. European Journal of Biochemistry 46, 83-88.

Clarke, M. \& Spudich, J. A. (1974). Biochemical and structural studies of actomyosin-like proteins from non-muscle cells. Journal of Molecular Biology 86, 209-222.

Coukell, M. B. (1981). Apparent positive cooperativity at a surface cAMP receptor in Dictyostelium. Differentiation 20, 29-35.

Dingermann, Th., Ogilvie, A., Pistel, F., MühlHOFER, W. \& KERSTEN, H. (1981). Reduced aminoacylation of asparagine-transfer RNA early in the developmental cycle of Dictyostelium discoideum: modification pattern and possible significance of the uncharged isoacceptor tRNA ${ }_{3}^{\text {sn }}$. Hoppe-Seyler's Zeitschrift für physiologische Chemie 362, 763-773.

Dowbenko, J. D. \& ENNIS, H. L. (1980). Regulation of protein synthesis during spore germination in Dictyostelium discoideum. Proceedings of the National Academy of Sciences of the United States of America 77, 1791-1795.

FARKAS, W. R. (1980). Effect of diet on the queuosine family of tRNAs of germ-free mice. Journal of Biological Chemistry 255, 6832-6835.

GarReLS, J. I. \& Gibson, W. (1976). Identification and characterization of multiple forms of actin. Cell $\mathbf{9}$, 793-805.

GerisCH, G. (1968). Cell aggregation and differentiation in Dictyostelium. Current Topics in Developmental Biology 3, 159-197.

GeRISCH, G. (1982). Chemotaxis in Dictyostelium. Annual Review of Physiology 44, 535-552.

Green, A. A. \& Newell, P. C. (1975). Evidence for the existence of two types of CAMP binding sites in aggregating cells of Dictyostelium discoideum. Cell 6, 129-136.

Hosbach, H. A. \& Kubli, E. (1979). Transfer RNA in ageing Drosophila. II. Isoacceptor patterns. Mechanisms of Ageing and Development 10, 141-149.

Howes, N. K. \& FARKas, W. R. (1978). Studies with a homogenous enzyme from rabbit erythrocytes catalyzing the insertion of guanine into tRNA. Journal of Biological Chemistry 253, 9082-9087.

KATZE, J. R. (1975). Alterations in SVT2 cell transfer RNAs in response to cell density and serum type. Biochimica et biophysica acta 383, 131-139.

KERSTEN, H. (1982). tRNA methylation: on the role of modified nucleosides in transfer-RNA. In Biochemistry of S-Adenosylmethionine and Related Compounds, pp. 357-369. Edited by E. Usdin, R. T. Borchardt \& C. R. Creveling. London: Macmillan.

KINDLE, K. L. \& FirTel, R. A. (1978). Identification and analysis of Dictyostelium actin genes, a family of moderately repeated genes. Cell 15, 763-778.

LiN, V. K., Farkas, W. R. \& Agris, P. F. (1980). Specific changes in Q-ribonucleoside containing transfer RNA species during Friend leukemia cell erythroid differentiation. Nucleic Acids Research 8 , 3467-3480.

LoOmis, W. F. (1975). Changes in metabolites during development. In Dictyostelium discoideum, a Developmental System, pp. 132-138. Edited by W. F. Loomis. New York, San Francisco, London: Academic Press.
MA, G. C. L. \& FirTeL, R. A. (1978). Regulation of the synthesis of two carbohydrate-binding proteins in Dictyostelium discoideum. Journal of Biological Chemistry 253, 3924-3932.

Mullens, I. A. \& Newell, P. C. (1978). cAMP binding to cell surface receptors of Dictyostelium. Differentiation 10, 171-176.

O'FARRELl (1975). High-resolution two-dimensional electrophoresis of proteins. Journal of Biological Chemistry 250, 4007-4021.

OKaDa, N., Shindo-OKada, N., SATO, S., ITOH, Y. H., ODA, K. J. \& NishimuRA, S. (1978). Detection of unique IRNA species in tumor tissues by Escherichia coli guanine insertion enzyme. Proceedings of the National Academy of Sciences of the United States of America 75, 4247-4251.

OTt, G., Kersten, H. \& Nishimura, S. (1982). Dictyostelium discoideum: a useful model system to evaluate the function of queuine and of the Q-family of tRNAs. FEBS Letters 146, 311-314.

RaHMSDORF, H. J., Malchow, D. \& Gerisch, G. (1978). Cyclic AMP-induced phosphorylation in Dictyostelium of a polypeptide comigrating with myosin heavy chains. FEBS Letters 88, 322-326.

Reyniers, J. P., Pleasants, J. R., Wostmann, B. S., KATZE, J. R. \& FARKAS, W. R. (1981). Administration of exogenous queuine is essential for the biosynthesis of the queuosine-containing transfer RNAs in the mouse. Journal of Biological Chemistry 256, 11591-11594.

Rubenstein, P. \& DeuchleR, J. (1979). Acetylated and nonacetylated actins in Dictyostelium discoideum. Journal of Biological Chemistry 254, $11142-$ 11147.

Schachner, E., Nishimura, S. \& Kersten, H. (1982). Development of Dictyostelium discoideum in the presence and absence of queuine and the queuine family of tRNAs. Hoppe-Seyler's Zeitschrift für physiologische Chemie 363, 887

Shindo-OKada, N., Terada, M. \& Nishimura, S. (1981). Changes in amount of hypo-modified tRNA having guanine in place of queuine during erythroid differentiation of murine erythroleukemia cells. European Journal of Biochemistry 115, 423-428.

Singhal, R. P., Kopper, R. A., Nishimura, S. \& SHINDO-OKADA, N. (1981). Modification of guanine to queuine in transfer RNAs during development and ageing. Biochemical and Biophysical Research Communications 99, 120-126.

Siu, Ch.-H., Lerner, R. A., MA, G., Firtel, R. A. \& LoOMIS, W. F. (1976). Developmentally regulated proteins of the plasma membrane of Dictyostelium discoideum. The carbohydrate-binding protein. Journal of Molecular Biology 100, 157-178.

Tuchman, J., Alton, T. \& Lodish, H. F. (1974). Preferential synthesis of actin during early development of the slime mold Dictyostelium discoideum. Developmental Biology 40, 116-128.

WATTS, D. J. \& AshwORTH, J. M. (1970). Growth of myxamoebae of the cellular slime mould Dictyostelium discoideum in axenic culture. Biochemical Journal 119, 171-174.

White, B. \& Tener, G. M. (1973). Activity of a transfer RNA modifying enzyme during the development of Drosophila and its relationship to the su(s) locus. Journal of Molecular Biology 74, 635-651. 